\title{
Biphasic Effects of Losartan Potassium on Immobility in Mice
}

\author{
Pandi ViJAYAPANDI and Anantha Naik NAGAPPA* \\ Pharmacy Group, Birla Institute of Technology and Science, Pilani-333031, Rajasthan, India
}

(Received April 11, 2005; Accepted May 30, 2005)

\begin{abstract}
The effects of losartan potassium, an angiotensin $\mathrm{AT}_{1}$ receptor blocker on immobility in forced swim test have been studied. Effect of losartan potassium, nortriptyline $\mathrm{HCl}$, fluoxetine $\mathrm{HCl}$ and reserpine per se and in combination on forced swimming-induced immobility in mice have also been studied. In mice, losartan potassium elicits biphasic responses i.e. positive responses at lower doses $(0.1,1.0$ and $5 \mathrm{mg} / \mathrm{kg}$, i.p. $)$ in the forced swim test, a test of potential antidepressant activity and vice versa at higher dose $(20$ and $100 \mathrm{mg} / \mathrm{kg}$, i.p.). In chronic studies, enhancement in immobility was observed for losartan potassium $(3$ and $30 \mathrm{mg} / \mathrm{kg}$, p.o., 21 days). In acute combination studies, losartan potassium (1 and $5 \mathrm{mg} / \mathrm{kg}$ ) significantly reversed the reserpine-induced immobility, but vice versa at $100 \mathrm{mg} / \mathrm{kg}$. Losartan potassium $(0.1$ and $5 \mathrm{mg} / \mathrm{kg})$ potentiate antidepressant activity of nortriptyline $(30 \mathrm{mg} / \mathrm{kg}$, i.p. $)$ in mice, but vice versa at $100 \mathrm{mg} / \mathrm{kg}$. Likewise, Losartan potassium $(100 \mathrm{mg} / \mathrm{kg})$, significantly reversed antidepressant activity of fluoxetine $\mathrm{HCl}$, but at 0.1 and $5 \mathrm{mg} / \mathrm{kg}$, failed to modify fluoxetine $\mathrm{HCl}$ induced immobility. The obtained biphasic effect of losartan potassium on immobility in mice might be due to inhibitory effect on $\mathrm{AT}_{1}$ receptor at lower dose and pronounced effect on $\mathrm{AT}_{2}$ receptor at higher dose (large concentrations of losartan potassium can displace Angiotensin II (Ang II) from its $\mathrm{AT}_{1}$ receptor to $\mathrm{AT}_{2}$ receptor.
\end{abstract}

Key words — - forced swim test; immobility time; losartan potassium; reserpine; nortriptyline; fluoxetine

\section{INTRODUCTION}

The presence of a separate renin angiotensin system (RAS) within the mammalian brain complete with the precursors and enzymes necessary for the formation and deactivation of the physiologically active forms of angiotensin (Ang) was supported in many investigations. ${ }^{1,2)}$ The effector peptide of the RAS Ang II, binds at least to two $G$ protein coupled receptor subtypes, referred to as the $\mathrm{AT}_{1}$ and the $\mathrm{AT}_{2}$ receptors. Ang II is known to stimulate catecholamine release ${ }^{3)}$ mediated by an $\mathrm{AT}_{1}$ subtype ${ }^{4)}$ is located on presynaptic nerve terminals. In case of $\mathrm{AT}_{1}$ receptor blockade, which is supposed to reduce catecholamine release leading to endogenous depression. Since deficiency of aminergic transmission in the CNS might be causative of endogenous depression. $\left.{ }^{5,6}\right)$ But on the converse, losartan an $\mathrm{AT}_{1}$ blocker elicits positive responses in the forced swim test, a test of potential antidepressant activity. ${ }^{7)}$ These controversial observations lead us to conduct studies on effects of losartan potassium on immobility in mice.

\section{MATERIALS AND METHODS}

Male albino mice (Swiss, 20-25 gm) used in these

e-mail: anantha@bits-pilani.ac.in studies were allowed food and water ad libitum up to the time of experimentation. Prior to use, the mice were housed in polypropylene cages in groups of six to eight animals under natural light-dark cycle. Institutional Animal Ethics Committee has approved all studies reported here (protocol Number IAEC/RES/ 5, dated 21/04/2003) .

Losartan potassium, fluoxetine $\mathrm{HCl}$ (Sun Pharma, India), nortriptyline $\mathrm{HCl}$ (Sigma, USA) were dissolved in normal saline and was given i.p. Reserpine (Loba Chemicals, India) was dissolved in a few drops of glacial acetic acid and the volume was makeup with normal saline. The drug solutions were prepared afresh at beginning of each experiment. In acute studies, all the drugs were administered by i.p. in a constant volume of $1 \mathrm{ml}$ per $100 \mathrm{gm}$ of body weight. In chronic studies, required dose of losartan potassium ( $3 \& 30 \mathrm{mg} / \mathrm{kg}$ ) was dissolved in per day consumption of drinking water $(12 \mathrm{ml} / 100 \mathrm{gm}$ of body weight) and made available for 21 days.

The behavioral despair test has been used as a test of depressive like behavior. ${ }^{8)}$ The animals were forced to swim individually in a glass cylinder $(30 \mathrm{~cm}$ high, $22.5 \mathrm{~cm}$ in diameter) containing $15 \mathrm{~cm}$ water at room temperature. The animals were individually trained in 15 min sessions, using the apparatus described above one day prior to the experimentation. During ex- 
perimentation each animal was placed on the cylinder one at a time and left there for $6 \mathrm{~min}$. The duration of immobility for each mouse was recorded. A mouse was judged to be immobile when it ceased struggling and remaining floating motionless in the water making only movements necessary to keep its head above water.

Statistical Analysis Results are presented as the mean \pm SEM. Experimental data in Table 1, were analyzed by one way analysis of variance (ANOVA) followed by post hoc comparisons between drug treated at various time intervals and vehicle treated control groups using Dunnett's test. In Table 2, experimental data were analyzed by one way analysis of variance (ANOVA) followed by Student's $t$-test. Statistical significance was set at $p<0.05$.

\section{RESULTS}

Effect of losartan potassium, nortriptyline $\mathrm{HCl}$, fluoxetine $\mathrm{HCl}$ and reserpine per se and in combination studies on forced swimming-induced immobility in mice is shown in Tables 1 and 2 . As shown in Table 1 , in comparison to control, losartan potassium $(0.1$, 1 and $5 \mathrm{mg} / \mathrm{kg}$, i.p.) significantly reduced immobility

Table 1. Effect of Losartan Potassium on Immobility in Mice

\begin{tabular}{|c|c|c|}
\hline Treatment (mg/kg, i.p.) & Duration of immobility (s) & ANOVA values \\
\hline Control & $284.31 \pm 4.00$ & \\
\hline Losartan potassium $(0.1)[1 \mathrm{~h}$ prior $]$ & $244.33 \pm 13.39^{*}$ & $F(4,25)=3.69$ \\
\hline Losartan potassium $(0.1)[3 \mathrm{~h}$ prior $]$ & $271.43 \pm 10.65$ & $p=0.0170$ \\
\hline Losartan potassium $(0.1)[6 \mathrm{~h}$ prior $]$ & $281.20 \pm 7.45$ & \\
\hline Losartan potassium $(0.1)[24 \mathrm{~h}$ prior $]$ & $283.82 \pm 5.02$ & \\
\hline Control & $284.21 \pm 11.10$ & \\
\hline Losartan potassium $(1.0)[1 \mathrm{~h}$ prior $]$ & $181.41 \pm 20.39^{* *}$ & $F(4,25)=9.02$ \\
\hline Losartan potassium $(1.0)[3 \mathrm{~h}$ prior $]$ & $249.07 \pm 19.87$ & $p=0.0001$ \\
\hline Losartan potassium (1.0) [6 h prior $]$ & $255.59 \pm 21.57$ & \\
\hline Losartan potassium $(1.0)[24 \mathrm{~h}$ prior $]$ & $286.46 \pm 8.42$ & \\
\hline Control & $274.41 \pm 3.41$ & \\
\hline Losartan potassium $(5.0)[1 \mathrm{~h}$ prior $]$ & $223.84 \pm 5.98^{* *}$ & $F(4,25)=23.07$ \\
\hline Losartan potassium $(5.0)[3 \mathrm{~h}$ prior $]$ & $233.09 \pm 6.72^{* *}$ & $p=0.0001$ \\
\hline Losartan potassium $(5.0)[6 \mathrm{~h}$ prior $]$ & $269.76 \pm 5.68$ & \\
\hline Losartan potassium $(5.0)[24 \mathrm{~h}$ prior $]$ & $277.97 \pm 3.65$ & \\
\hline Control & $296.41 \pm 14.55$ & \\
\hline Losartan potassium $(10)[1 \mathrm{~h}$ prior $]$ & $307.67 \pm 15.29$ & $\mathrm{~F}(4,25)=0.11$ \\
\hline Losartan potassium $(10)[3 \mathrm{~h}$ prior $]$ & $308.96 \pm 14.9$ & $p=0.9759$ \\
\hline Losartan potassium $(10)[6 \mathrm{~h}$ prior $]$ & $302.25 \pm 14.39$ & \\
\hline Losartan potassium (10) $[24 \mathrm{~h}$ prior $]$ & $304.45 \pm 8.76$ & \\
\hline Control & $293.32 \pm 7.08$ & \\
\hline Losartan potassium $(20)[1 \mathrm{~h}$ prior $]$ & $309.62 \pm 9.49$ & $F(4,25)=10.19$ \\
\hline Losartan potassium $(20)[3 \mathrm{~h}$ prior $]$ & $320.10 \pm 6.42^{*}$ & $p=0.0001$ \\
\hline Losartan potassium $(20)[6 \mathrm{~h}$ prior $]$ & $328.43 \pm 4.14^{* *}$ & \\
\hline Losartan potassium $(20)$ [24 h prior $]$ & $283.73 \pm 5.81$ & \\
\hline Control & $284.67 \pm 4.2$ & \\
\hline Losartan potassium $(100)$ [1 h prior $]$ & $312.42 \pm 3.05^{* *}$ & $\mathrm{~F}(4,25)=17.19$ \\
\hline Losartan potassium $(100)$ [3 h prior $]$ & $321.44 \pm 6.85^{* *}$ & $p=0.0001$ \\
\hline Losartan potassium $(100)[6 \mathrm{~h}$ prior $]$ & $309.90 \pm 2.97^{* *}$ & \\
\hline Losartan potassium $(100)[24 \mathrm{~h}$ prior $]$ & $302.69 \pm 3.38^{* *}$ & \\
\hline \multicolumn{3}{|l|}{ Chronic treatment for 21 days } \\
\hline Control & $118.85 \pm 2.84$ & \\
\hline Losartan potassium (3) & $216.39 \pm 15.65^{* *}$ & $\mathrm{~F}(2,15)=34.51$ \\
\hline Losartan potassium $(30)$ & $259.46 \pm 14.10^{* *}$ & $p=0.0001$ \\
\hline
\end{tabular}

6 min test. Values are means \pm S.E. of 6 animals in each group. ${ }^{*} p<0.05$, ${ }^{* *} p<0.01$ (one-way ANOVA/Dunnett's test: as compared to control group). 
Table 2. Effect of Losartan Potassium upon Nortriptyline $\mathrm{HCl}$, Fluoxetine $\mathrm{HCl}$ and Reserpine-induced Immobility on Forced Swimming in Mice

\begin{tabular}{|c|c|c|}
\hline Treatment (mg/kg, i.p.) & Duration of immobility (s) & ANOVA values \\
\hline Control & $286.69 \pm 9.83$ & \\
\hline Reserpine (2) $[5 \mathrm{~h}$ prior $]$ & $322.09 \pm 8.85^{* a}$ & $\mathrm{~F}(6,35)=20.17$ \\
\hline Reserpine (2) $[24 \mathrm{~h}$ prior $]$ & $320.80 \pm 11.29^{* a}$ & $p=0.0001$ \\
\hline Reserpine (2) $[5 \mathrm{~h}$ prior $]+$ Losartan potassium $(100)[3 \mathrm{~h}$ prior $]$ & $339.43 \pm 4.17^{* \mathrm{~b}}$ & \\
\hline Reserpine (2) $[5 \mathrm{~h}$ prior $]+$ Losartan potassium $(20)[3 \mathrm{~h}$ prior $]$ & $310.97 \pm 9.07$ & \\
\hline Reserpine (2) $[5 \mathrm{~h}$ prior $]+$ Losartan potassium $(5)[3 \mathrm{~h}$ prior $]$ & $277.63 \pm 13.76^{* \mathrm{~b}}$ & \\
\hline Reserpine (2) $[5 \mathrm{~h}$ prior $]+$ Losartan potassium (1) $[1 \mathrm{~h}$ prior $]$ & $202.38 \pm 19.62^{* b}$ & \\
\hline Control & $312.42 \pm 2.7$ & \\
\hline Nortriptyline $\mathrm{HCl}(10)[1 \mathrm{~h}$ prior $]$ & $311.53 \pm 6.96$ & $F(6,35)=13.71$ \\
\hline Nortriptyline $\mathrm{HCl}(30)[1 \mathrm{~h}$ prior $]$ & $244.56 \pm 10.40^{* * * a}$ & $p=0.0001$ \\
\hline Nortriptyline $\mathrm{HCl}(30)[1 \mathrm{~h}$ prior $]+$ Losartan potassium $(100)[3 \mathrm{~h}$ prior $]$ & $307.63 \pm 17.02 * *_{c}$ & \\
\hline Nortriptyline $\mathrm{HCl}(30)[1 \mathrm{~h}$ prior $]+$ Losartan potassium $(20)[3 \mathrm{~h}$ prior $]$ & $276.94 \pm 17.07$ & \\
\hline Nortriptyline $\mathrm{HCl}(30)[1 \mathrm{~h}$ prior $]+$ Losartan potassium $(5)[3 \mathrm{~h}$ prior $]$ & $214.39 \pm 5.43 *_{\mathrm{c}}$ & \\
\hline Nortriptyline $\mathrm{HCl}(10)[1 \mathrm{~h}$ prior $]+$ Losartan potassium $(0.1)[1 \mathrm{~h}$ prior $]$ & $230.70 \pm 18.38^{* d}$ & \\
\hline Control & $295.02 \pm 13.56$ & \\
\hline Fluoxetine $\mathrm{HCl}(10)[1 \mathrm{~h}$ prior $]$ & $292.96 \pm 20.66$ & $F(6,35)=13.49$ \\
\hline Fluoxetine $\mathrm{HCl}(30)[1 \mathrm{~h}$ prior $]$ & $203.09 \pm 10.89^{* * * a}$ & $p=0.0001$ \\
\hline Fluoxetine $\mathrm{HCl}(30)[1 \mathrm{~h}$ prior $]+$ Losartan potassium $(100)[3 \mathrm{~h}$ prior $]$ & $244.42 \pm 9.62^{*_{\mathrm{e}}}$ & \\
\hline Fluoxetine $\mathrm{HCl}(30)[1 \mathrm{~h}$ prior $]+$ Losartan potassium $(20)[3 \mathrm{~h}$ prior $]$ & $230.13 \pm 14.52$ & \\
\hline Fluoxetine $\mathrm{HCl}(30)[1 \mathrm{~h}$ prior $]+$ Losartan potassium $(5)[3 \mathrm{~h}$ prior $]$ & $165.35 \pm 23.17$ & \\
\hline Fluoxetine $\mathrm{HCl}(10)[1 \mathrm{~h}$ prior $]+$ Losartan potassium $(0.1)[1 \mathrm{~h}$ prior $]$ & $315.07 \pm 7.26$ & \\
\hline
\end{tabular}

6 min test. Values are means \pm S.E. of 6 animals in each group. $p$ values: ${ }^{*}<0.05,{ }^{*}<0.01, * * *<0.001$ as compared between treatment. (a) Control group, (b) reserpine $(2 \mathrm{mg} / \mathrm{kg}) 5 \mathrm{~h}$ prior group, (c) nortriptyline $\mathrm{HCl}(30 \mathrm{mg} / \mathrm{kg}) 1 \mathrm{~h}$ prior group, (d) nortriptyline $\mathrm{HCl}(10 \mathrm{mg} / \mathrm{kg}) 1 \mathrm{~h} \mathrm{prior} \mathrm{group} \mathrm{and} \mathrm{(e)} \mathrm{fluoxetine}$ $\mathrm{HCl}(30 \mathrm{mg} / \mathrm{kg}) 1 \mathrm{~h}$ prior group

in the mouse forced swim test, but at 20 and $100 \mathrm{mg}$ / $\mathrm{kg}$, i.p. significantly increased immobility. In chronic studies, when compare to control, losartan potassium (3 and $30 \mathrm{mg} / \mathrm{kg}$, p.o., 21 days) significantly enhance immobility in mice (Table 1). As shown in Table 2, losartan potassium (1 and $5 \mathrm{mg} / \mathrm{kg}$ ) significantly reversed the reserpine-induced immobility in mice, but enhanced in immobility at $100 \mathrm{mg} / \mathrm{kg}$. Losartan potassium $(0.1$ and $5 \mathrm{mg} / \mathrm{kg})$ potentiated antidepressant activity of nortriptyline $(30 \mathrm{mg} / \mathrm{kg}$, i.p. $)$ in mice, but at $100 \mathrm{mg} / \mathrm{kg}$, significantly reversed it. Likewise, Losartan potassium $(100 \mathrm{mg} / \mathrm{kg})$, significantly reversed antidepressant activity of fluoxetine $\mathrm{HCl}$, but at 0.1 and $5 \mathrm{mg} / \mathrm{kg}$, failed to modify fluoxetine $\mathrm{HCl}$ induced immobility.

\section{DISCUSSION}

It has been previously reported, the antidepressant drugs desipramine, fluoxetine and tranylcypromine are able to antagonize the effects of Ang in rats, both in vivo and in vitro. ${ }^{9)}$ Giardina and Ebert ${ }^{10)}$ (1989) showed that captopril elicits antidepressant like effects in an animal model and extend the previous work by showing that losartan has similar actions. ${ }^{7)}$ Based on these observations, it has been hypothesized that inhibition of Ang function is important in the treatment of endogenous depression. The results of present studies showed biphasic effects of losartan potassium on immobility in mice (i.e.) reduced immobility at lower dose $(0.1,1$ and $5 \mathrm{mg} / \mathrm{kg})$ enhanced immobility in higher dose $(100 \mathrm{mg} / \mathrm{kg}, \mathrm{i} . \mathrm{p}$.$) .$ The biphasic effect was further confirmed by interaction of losartan potassium with reserpine and antidepressant drugs nortriptyline and fluoxetine (Table 2). Nahmod et al found Ang II to cause 5HT release and accelerate its synthesis in biphasic manner, stimulating at high doses and inhibiting at lower doses. ${ }^{11)}$ Using the micro dialysis technique, it was demonstrated that stimulation of periventricular $\mathrm{AT}_{1}$ receptors leads to release of noradrenaline in the paravetricular nucleus and the supraoptic nucleus. ${ }^{12,13)}$

The research on the Ang receptor subtype characterization in the brain has been reviewed. ${ }^{14)}$ Both the $\mathrm{AT}_{1}$ and $\mathrm{AT}_{2}$ receptors have been localized in the brain $\mathrm{RAS}^{15)}$ together with their mRNAs. ${ }^{16)}$ In ro- 
dents $\mathrm{AT}_{1 \mathrm{~A}}$ receptor has been found in brain areas involved in blood pressure and fluid homeostasis. The $\mathrm{AT}_{1 \mathrm{~B}}$ receptor is present in glandular tissues, such as anterior pituitary, pineal, adrenal gland, and testes. ${ }^{17)}$ The $\mathrm{AT}_{2}$ receptor is densely expressed in the lateral septum, in several thalamic nuclei, in sub thalamic nucleus, in locus cerules and in the inferior olive. ${ }^{18)}$ Activation of $\mathrm{AT}_{2}$ receptor seems to induce effects opposite to that of $\mathrm{AT}_{1} \cdot{ }^{19)} \mathrm{AT}_{2}$ stimulation inhibits drinking responses and vasopressin release following centrally administered Ang II, ${ }^{20)}$ promotes differentiation and axonal regeneration, and inhibits proliferation of neuronal cells. ${ }^{21}$ ) Thus the counteracting effects between $\mathrm{AT}_{1}$ and $\mathrm{AT}_{2}$ receptors suggest that a negative cross talk exist between the $\mathrm{AT}_{1}$ and $\mathrm{AT}_{2}$ receptors, ${ }^{22)}$ as is the case in catecholaminergic neurons. ${ }^{23)}$ Most of the central effects of Ang peptides, which are mediated by $\mathrm{AT}_{1}$ receptor, are under control by $\mathrm{AT}_{2}$ receptor. They are in accordance with earlier findings from in vitro experiments in endothelial cells where growth promoting effects mediated by $\mathrm{AT}_{1}$ receptors were counteracted by growth inhibitory actions of $\mathrm{AT}_{2}$ receptors. ${ }^{24}$ Opposite effects of $\mathrm{AT}_{1}$ and $\mathrm{AT}_{2}$ receptors on the second messenger phosphatidylinositol have also been described by Gyurko et al. ${ }^{25)} \mathrm{AT}_{1}$ selective receptor antagonists are known to bind to $\mathrm{AT}_{2}$ receptors with low affinity and vice versa. However, the selectivity is not absolute, and large concentrations of $\mathrm{AT}_{1}$ selective receptor antagonists can displace Ang II from $\mathrm{AT}_{1}$ receptors to the alternative site $\left(\mathrm{AT}_{2}\right.$ receptors) . ${ }^{26)}$ The obtained biphasic effect of losartan potassium on immobility in mice might be due to inhibitory effect on $\mathrm{AT}_{1}$ receptor at lower dose and pronounced effect on $\mathrm{AT}_{2}$ receptor at higher dose (large concentrations of losartan potassium can displace Ang II from its $\mathrm{AT}_{1}$ receptor to $\mathrm{AT}_{2}$ receptor). In chronic studies with losartan potassium even at lower dose $(3 \mathrm{mg} / \mathrm{kg}$, p.o.) potentiated immobility in mice, which might be due to continuous blockade of $\mathrm{AT}_{1}$ receptor resulting in unopposed $\mathrm{AT}_{2}$ receptor stimulation. It has also been previously reported that the treatment of Ang II for $4 \mathrm{~h}$ has a biphasic effect on $\mathrm{Na}^{+}$transport in the primary cultured rabbit renal proximal tubule cells (PTCs); a Pico molar range of Ang II stimulates $\mathrm{Na}^{+}$transport, whereas a micro molar range of Ang II inhibits it. ${ }^{27)}$

Antagonist $\mathrm{IC}_{50}\left(8.78 \pm 0.11 \times 10^{-9} \mathrm{M}\right)$ and $\mathrm{Ki}$ values $\left(41.57 \pm 5.09 \times 10^{-9} \mathrm{M}\right)$ of losartan from com- petition binding experiments with $\left[{ }^{125} \mathrm{I}\right] \mathrm{Sar}^{1}-\mathrm{Ilu}^{8}$ Ang II on intact Chinese Hamster Ovary Cells expressing the transfected human $\mathrm{AT}_{1}$ receptor $\left(\mathrm{CHO}-\mathrm{hAT}_{1}\right.$ cells) was described. ${ }^{28)}$ Effects of Ang II on $\mathrm{AT}_{1}$ and $\mathrm{AT}_{2}$-binding sites and mRNAs in Bovine adrenal fasciculata cells (BAC) have been demonstrated. ${ }^{29)}$ In these studies, treatment of cells with increasing concentrations of Ang II caused a dose-dependent inhibition of $\mathrm{AT}_{1}$ and $\mathrm{AT}_{2}$ binding sites and mRNAs. The maximal inhibitory effect was observed at $10^{-7} \mathrm{M}$, but the $\mathrm{IC}_{50}$ for $\mathrm{AT}_{1}$ and $\mathrm{AT}_{2}$-binding sites and $\mathrm{AT}_{1}$ mRNA $\left(3 \pm 0.43 \pm 10^{-9} \mathrm{M}\right)$ were significantly higher than that for $\mathrm{AT}_{2}$ mRNA $\left(2.8 \pm 0.3 \times 10^{-10} \mathrm{M}\right)$. However, the most striking differences were observed in the time-course effects of Ang II. $\mathrm{AT}_{1}$-binding sites decreased very rapidly, and by $3 \mathrm{~h}$, more than $50 \%$ of the surface receptors disappeared. In contrast, the effects of Ang II on $\mathrm{AT}_{2}$-binding sites were not significant during the first hours of treatment. Thereafter, the surface receptor declined with an apparent half-life of $14-16 \mathrm{~h}$. Similarly, the effects on $\mathrm{AT}_{2}$ mRNA were not significant during the first $6 \mathrm{~h}$ of treatment, but then the levels dramatically decreased, with an apparent half-life of $2 \mathrm{~h} .{ }^{29)}$ In higher doses of losartan potassium ( 20 and $100 \mathrm{mg} / \mathrm{kg}$, i.p.) enhancement in immobility was observed even after $3 \mathrm{hs}$ of losartan potassium treatment. The terminal half-life of losartan p.o. is $2.12 \mathrm{~h}$ and its active metabolite EXP 3174 (carboxylic acid derivative) about 6 to $9 \mathrm{~h} .{ }^{30)}$ It is reported that the effect of i.p. administration of losartan $(20 \mu \mathrm{mol} / \mathrm{kg})$ on Ang II induced drinking was found to be reduced at 4, 12 and $24 \mathrm{~h}$. EXP 3174 significantly reduced the Ang II induced water intake even at $0.25 \mathrm{~h}$. Therefore, the ability of peripherally administered losartan influencing central Ang mechanisms might be accounted for EXP 3174, which is about 20 times more potent than losartan to inhibit central $\mathrm{AT}_{1}$ receptors and which apparently crosses the blood-brain barrier rather well. ${ }^{31)}$

\section{ACKNOWLEDGEMENTS}

The authors wish to thank the Director, Birla Institute of Technology \& Science, Pilani. for providing facilities to this work.

\section{REFERENCES}

1) Ganten D., Minnich J. E., Granger P., Hayduk K., Brecht H. M., Barbeau A., Boucher R., Genest J., Science, 173, 64-65 (1971). 
2) Ganten D., Hermann K., Bayer C., Unger T., Lang R. E., Science, 221, 869-871 (1983).

3) Zimmerman B. G., Clin. Sci. (London), 60, 343-348 (1981).

4) Mendelsohn F. A., Jenkins T. A., Berkovic S. F., Brain Res., 613, 221-229 (1993).

5) Hardman J. G., Limbird L. E., Gilman A. G., "Goodman \& Gilman's the Pharmacological Basis of Therapeutics," 10th ed., McGrawHill, New York, 2001, pp. 449-450.

6) Okpako D. T., "Principles of Pharmacology," 2nd ed., Cambridge University Press, Cambridge, 2002, pp. 529-530.

7) Gard P. R., Mandy A., Sutcliffe M. A., Biol. Psychiatry, 45, 1030-1034 (1999).

8) Sharma A., Kulkarni S. K., Indian J. Exp. Biol., 32, 172-175 (1994).

9) Gard P. R., Mandy A., Whiting J. M., Nickels D. P. D., Meakin A. J. L. S., Eur. J. Pharmacol., 264, 295-300 (1994).

10) Giardina W. J., Ebert D. M., Biol. Psychiatry, 25, 697-702 (1989).

11) Nahmod V. E., Finkieman S., Benarrock E. E., Pirola C. J., Science, 202, 1091-1093 (1978).

12) Stadler T., Veltmar A., Quadri F., Unger T. H., Brain Res., 569, 117-122 (1992).

13) Quadri F., Culman J., Veltmar A., Maas K., Rascher W., Unger T. H., J. Pharmacol. Exp. Ther., 267, 567-574 (1993).

14) Allen A., MacGregor D., McKinley M., Mendelsohn F., Regul. Pept., 79, 1-7 (1999) .

15) Allen A., Moeller I., Jenkins T., Zhuo J., Aldred G., Chai S., Mendelsohn F., Brain Res. Bull., 47, 17-28 (1998).

16) Bunnemann B., Iwai N., Metzger R., Fuxe K., Inagami T., Ganden D., Neurosci. Lett., 142, 155-158 (1992).

17) Davisson R., Oliverio M., Coffman T., Sig- mund C., J. Clin. Invest., 106, 103-106 (2000) .

18) Heemskerk F., Zorad S., Seltzer A., Saavedra J., Neuroreport, 4, 103-105 (1993).

19) Unger T., J. Hypertens., 17, 1775-1786 (1999).

20) Hohle S., Spitznagel H., Rascher W., Culman J., Unger T., Eur. J. Pharmacol., 275, 277282 (1995).

21) Gendron L., Laflamme L., Rivard N., Asselin C., Payet M., Gallo-Payet N., Mol. Endocrinol., 13, 1615-1626 (1999).

22) Horiuchi M., Lehtonen J., Daviet L., Trends Endocrinol. Metab., 10, 391-396 (1999).

23) Gelband C., Zhu M., Lu D., Reagan L., Fluharty S., Posner P., Raizada M., Sumners C., Endocrinol., 138, 2195-2198 (1997).

24) Stoll M., Steckelings U. M., Botari S. P., Paul M., Metzger R., Unger T.H., J. Clin. Invest., 95, 651-657 (1995).

25) Gyurko R., Kumura B., Kurian P., Crews F. T., Phillips M. I., Biochem. Biophys. Res. Commun., 186, 285-292 (1992).

26) Saavedra J. M., Regul. Pept., 85, 31-45 (1999).

27) Han H J., Park S. H., Koh H. J., Taub M., Kidney Int., 57, 2457-2467 (2000).

28) Vanderheyden P. M. L., Fierens F. L. P., De Backer J. P., Vauquelin G., Br. J. Pharmacol., 126, 1057-1063 (1999).

29) Ouali R., Berthelon M. C., Begeot M., Saez J. M., Endocrinol., 138, 725-733 (1997).

30) Christen Y., Waeber B., Nussberger J., Lee R. J., Timmermans P. B. M. W. M., Brunner H. R., Am. J. Hypertens., 4, 3505-3535 (1991).

31) Polidori C., Ciccocioppo R., Pompei P., Cirillo R., Massi M., Eur. J. Pharmacol., 307, 259 -267 (1996). 